\title{
ANALISIS WACANA KRITIS DALAM PEMBELAJARAN: PERAN AWK PADA PEMBELAJARAN LITERASI KRITIS, BERPIKIR KRITIS, DAN KESADARAN BERBAHASA KRITIS
}

\author{
Oleh: \\ Ruruh Sarasati \\ ruruhsaraswati@uny.ac.id \\ Fakultas Bahasa dan Seni Universitas Negeri Yogyakarta
}

\begin{abstract}
ABSTRAK
Analisis wacana kritis selama ini digunakan untuk mengetahui hubungan kekuasaan yang terjadi dalam proses produksi dan reproduksi makna. Struktur pengetahuan mempengaruhi jalannya praktik kewacanaan. Pengetahuan yang dimaksud bukan hanya pengetahuan yang diketahui oleh penutur, akan tetapi pengetahuan pendengar atau pembaca. Hal tersebut menempatkan analisis wacana kritis dalam sifat multidisipliner. Sifat multidisipliner yang saat ini melekat pada analisis wacana kritis memunculkan potensi keterlibatan analisis wacana kritis dalam wacana-wacana yang timbul di kelas. Lebih lanjut lagi, analisis wacana kritis juga dapat berperan dalam pembelajaran. Dalam artikel ini disampaikan potensi peran Analisis Wacana Kritis dalam pembelajaran literasi kritis, berpikir kritis, dan kesadaran berbahasa kritis.
\end{abstract}

Kata kunci: analisis wacana kritis, literasi kritis, berpikir kritis, dan kesadaran berbahasa kritis

\begin{abstract}
Critical discourse analysis has been used to determine the power relations that occur in the process of production and reproduction of meaning. The structure of knowledge influences the course of the practice of discoure. The intended knowledge is not only knowledge that is known by the speaker, but the knowledge of the listener or reader. This places critical discourse analysis in a multidisciplinary view. The multidisciplinary view is currently inherent in the analysis of critical discourse and raises the potential for the involvement of critical discourse analysis in the discourses that arise in the classroom. Furthermore, critical discourse analysis can also play a role in learning. This article conveys the potential role of Critical Discourse Analysis in critical literacy learning, critical thinking, and critical language awareness.
\end{abstract}

Keywords: critical discourse analysis, critical literacy, critical thinking, and critical language awareness 


\section{PENDAHULUAN}

Analisis wacana kritis semula dilakukan untuk menyelidiki secara kritis adanya ketidakseimbangan sosial yang diekspresikan dalam bentuk penggunaan bahasa wacana (Weiss dan Wodak, 2002: 13). Analisis wacana kritis melihat teks sebagai tindak tutur, dengan demikian, analisis wacana kritis berefek pada bagaimana suatu bahasa digunakan dan bagaimana sebuah makna dapat terbentuk. Sifat multidisipliner yang kini tersemat dalam analisis wacana kritis berimplikasi pada penggunaan analisis wacana kritis untuk beragam fungsi dalam teori dan metode penelitian (Weiss dan Wodak, 2002: 15).

Keberadaan analisis wacana kritis sebagai ilmu yang bersifat multidisipliner membawa implikasi termasuk implikasi pedagogis. Wacana yang terbentuk di dalam kelas memiliki peranan yang cukup kuat (cari kajian atau apa yang menyatakan bahwa wacaana dan apa yang terjadi di dalam kelas terutama kelas bahasa memiliki

Analisis wacana kritis juga memiliki implikasi pedagogis. Sekolah ikut terlibat dalam perkembangan umum bahasa dalam hubungannya dengan kekuasaan (Fairclough dalam Burns dan Morrel: 7). Sekolah dan lembaga pendidikan lainnya memiliki tanggung jawab untuk menciptakan siswa yang dapat berperan sebagai warga negara dengan kesadaran berbahasa kritis yang baik.

Analisis wacana kritis dapat diposisikan dalam bentuk metawacana pada sebuah diskusi kelas; siswa mendiskusikan bagaimana seorang siswa atau sekelompok siswa menggunakan bahasa untuk menyampaikan maksud. Dari penggunaan bahasa tersebut, dapat diketahui nilai, kepercayaan, dan ideologi yang dianut oleh seorang atau sekelompok siswa. Informasi-informasi yang diperoleh melalui analisis wacana ini dapat digunakan sebagai data bagi guru untuk mengembangkan pembelajarannya. Analisis wacana kritis bahkan dapat digunakan oleh guru untuk melakukan penilaian terhadap performansi berbicara siswa dan bagaimana siswa menggunalan bahasa untuk merefleksikan pengalaman pendidikan yang diterima dalam konteks sekola

Berbagai keterlibatan analisis wacana (termasuk analisis wacana kritis) dalam ranah pendidikan dan pembelajaran bahasa tersebut menunjukkan adanya potensi analisis wacana untuk dapat digunakan sebagai salah satu alat untuk meningkatkan pembelajaran, baik berupa pengalaman belajar maupun hasil belajar yang diharapkan oleh guru. Artikel ini 
ditulis sebagai upaya untuk menyampaikan gagasan mengenai peran analisis wacana, khususnya analisis wacana kritis, dalam meningkatkan kemampuan berpikir kritis siswa. Selain kemampuan berpikir kritis, kesadaran berpikir kritis dan kemampuan literasi kritis merupakan dua hal lainnya yang melibatkan peran serta analisis wacana kritis. Dengan analisis wacana kritis tersebut, siswa diharap mampu menangkap ideologi dan mencapai tujuan tertentu. Melalui literasi kritis, siswa diharapkan menjadi lebih sadar terhadap maksud yang disampaikan oleh penulis buku dan tidak menerima setiap informasi sebagai kebenaran yang utuh.

\section{ANALISIS WACANA KRITIS}

Analisis wacana kritis merupakan salah satu jenis praktik analisis wacana. Analisis wacana kritis mulai berkembang pada akhir 1970 berhubungan dengan bentuk wacana, proses terbentuknya wacana, proses membaca, dan potensi sosial melalui analisis opini secara kritis dan penjelasan wacana untuk memperoleh titik temu antara bahasa, ideology, dan hak asasi (Pang dan Wu, 2009: 148). Analisis Wacana Kritis menjembatani perbedaan antara analisis wacana langsung dan analisis wacana tidak langsung (Burns dan Morrell: 2). Analisis wacana langsung merupakan bentuk analisis wacana yang memiliki hubungan langsung dengan analisis linguistik, sementara analisis tidak langsung berhubungan dengan aspekaspek kontekstual linguistik.

Tercatat tiga tokoh pionir pada studi analisis wacana kritis. Ketiga tokoh tersebut; van Dijk, Wodak, dan Fairclough memiliki definisi dan prinsip analisis wacana kritis yang berbeda satu sama lain. Van Dijk (1993: 249) mendefinisikan analisis wacana kritis sebagai studi hubungan antara wacana, kekuasaan, dominasi, ketidakseimbangan sosial, dan posisi analis wacana dalam sebuah hubungan sosial. Oleh karena menyelidiki hubungan kekuasaan, dominasi, dan analis wacana kritis, analisis wacana kritis model ini disebut analisis wacana kritis model sosio-kognitif (Sheyholislami, 2001: 3). Dari definisi ini, van Dijk memandang analisis wacana sebagai sebuah studi yang kompleks dan bersifat multidisipliner. Meskipun demikian, fokus kajian van Dijk terletak pada peran wacana dalam produksi dan reproduksi dominasi. Analisis wacana kritis van Dijk merupakan analisis wacana yang paling banyak dirujuk dan digunakan dalam analisis kritis wacana media.

Analisis wacana kritis van Dijk memiliki wilayah ketercakupan yang lebih luas. Van Dijk tidak hanya berada pada level tekstual dan struktural dari wacana media saja, melainkan, dapat pula 
digunakan untuk analisis dan penjelasan pada level produksi dan resepsi atau pemahaman (Boyd-Barret dalam Sheyholislami, 2001: 3). Pada level mikrostruktur, misalnya, analisis wacana kritis difokuskan pada hubungan semantik antara proposisi, sintaksis, leksikal, dan elemen-elemen retorika yang lain yang lain; kutipan, laporan langsung, dan laporan tidak langsung. Analisis pada level mikrostruktur dan makrostruktur dari teori van Dijk lebih banyak digunakan untuk analisis media sehingga analisis wacana kritis dalam perspektif ini meliputi:

a) menyelidiki konteks wacana yang meliputi konteks historis, politis, dan latar belakang sosial sebuah konflik dan pihak yang terlibat di dalamnya,

b) menganalisis kelompok, hubungan kekuasaan, serta konflik yang melingkupi,

c) mengidentifikasi opini positif dan negatif mengenai kelompok "kami” vs kelompok "mereka"

d) mengungkap makna eksplisit dari presuposisi dan kata-kata implisit lainnya

e) menguji seluruh struktur formal untuk membantu memilah kutub antar kelompok-kelompok yang beropini.

Tokoh lain, Wodak menekankan wacana sosiolinguistik sebagai salah satu arah analisis wacana kritis. Pendekatan wacana sosiolinguistik ini meng- identifikasi dan mendeskripsikan mekanisme dasar yang berkontribusi terhadap "kecacatan" wacana yang terjadi dalam konteks tertentu dan berefek pada komunikasi (Sheyholislami, 2001: 4). Wacana sosiolinguistik ini kemudian dikembangkan menjadi metode wacana historis yang mengisyaratkan adanya usaha untuk mengintegrasikan semua latar belakang secara sistematis dalam analisis dan interpretasi dari berbagai lapisan teks lisan dan tertulis. Pemfokusan pada konteks historis dari sebuah wacana dalam proses penjelasan dan interpretasi ini membedakan metode wacana historis dengan pendekatan-pendekatan analisis wacana kritis lainnya, termasuk analisis wacana kritis van Dijk.

Selain ancangan analisis wacana kritis oleh van Dijk dan Wodak, Fairclough (2012) juga mengembangkan gagasan analisis wacana kritis. Gagasan yang dikembangkan oleh Fairclough sebelumnya telah dikemukakan oleh Williams (Fairclough, 2012) mengenai semiotika sebagai elemen yang tidak terpisahkan dari proses sosial; sebuah proses yang terjalin dari praktik-praktik sosial berbagai kegiatan yang berbeda. Analisis wacana kritis dalam pandangan Fairclough adalah sebuah analisis terhadap hubungan dialektikal antara wacana (yang terdiri atas bahasa dan bentuk-bentuk semiotika yang lain; antara lain bahasa 
tubuh dan gambar visual) dan elemenelemen praktik sosial lainnya. Dengan demikian, wacana dibangun oleh adanya struktur sosial dan budaya dan diproses dengan menyelidiki hubungan antara a) teks sebagai tindak tutur, b) praktik kewacanaan yang menyertai sebuah teks, c) serta konteks sosiokultural yang menjadi wahana penciptaan sebuah teks dan penggunaannya (Fairclough, 1995; Sheyholislami, 2001: 6).

Perbedaan utama antara ancangan analisis van Dijk dan Fairclough terletak pada dimensi kedua yakni mengenai praktik kewacanaan yang menyertai sebuah teks. Van Dijk mengajukan kognisi sosial dan model mental sebagai penghubung antara wacana dan sosial, sementara Fairclough menyerahkan tugas tersebut pada praktik kewacanaan berupa produksi dan konsumsi teks. Berikut adalah penjelasan mengenai fokus model analisis wacana kritis menurut Fairclough (Sheyholislami, 2001: 7).

a. Teks

Analisis teks melibatkan analisis unsur linguistik berupa kosakata, tata bahasa, semantik, sistem bunyi, dan kohesi atau organisasi di atas level kalimat. Teks dipandang dari berbagai perspektif dan memiliki berbagai fungsi, yaitu fungsi representasi, relasi, dan identitas berupa: a) representasi dan rekontekstualisasi praktik sosial yang mungkin menyembunyikan atau membawa ideologi tertentu, b) konstruksi tertentu dari identitas penulis dan pembaca, termasuk aspek individual dan personal dalam suatu identitas tertentu, c) konstruksi tertentu dari hubungan antara penulis dan pembaca.

b. Praktik Wacana

Terdapat dua dimensi praktik wacana, yaitu proses institusional (berupa prosedur pengeditan teks) dan proses wacana (mengubah teks sesuai konteks produksi dan konsumsi yang dilakukan). Proses wacana berada pada pertengahan antara sisi sosial budaya dan wacana, bahasa, dan teks di sisi yang lain. Pada fokus praktik wacana ini, akan muncul analisis intertekstual yang merujuk pada analisis linguistik pada level praktik wacana. Analisis intertekstual terletak di antara teks dan praktek wacana, sehingga analisis intertekstual ini memandang teks dari sudut panda praktik kewacanaan serta melihat jejak praktik wacana dalam sebuah teks. Piranti intertekstual sebuah teks terletak pada ciri linguistiknya; ciri linguistik mampu menyediakan berbagai bukti yang dapat digunakan dalam analisis intertekstual.

c. Praktik Sosiokultural

Setidaknya terdapat tiga praktik sosikultural yang menjadi dimensi analsisis sebuah peristiwa komunikatif. Ketiganya adalah: ekonomi, politik, dan budaya. Tidak semua dimensi harus 
diikutsertakan dalam analisis wacana sebuah teks.

Analisis wacana kritis yang dapat digunakan untuk meningkatkan kemampuan berpikir kritis siswa adalah ancangan analisis wacana kritis yang disampaikan oleh Fairclough berdasar pertimbangan adanya teks, praktik kewacanaan (produksi dan resepsi teks), serta praktik sosial budaya. Ketiga hal tersebut dapat diamati secara langsung di dalam kelas. Keberadaan ketiga praktik kewacanaan tersebut memungkinkan guru untuk menerapkan analisis wacana kritis sebagai sarana untuk melatih dan meningkatkan kemampuan berpikir kritis siswa, termasuk dalam upaya meningkatkan kemampuan literasi kritis dan kemampuan berbahasa kritis siswa.

\section{ANALISIS WACANA KRITIS DAN} PERANANNYA DALAM PEMBE-

\section{LAJARAN}

Perubahan linguistik pada ilmu sosial membawa dampak pada penelitian di bidang pendidikan, tidak terkecuali analisis wacana kritis, yang dianggap sebagai salah satu bagian dari metodologi dan pendekatan studi bahasa dan teks yang terbentuk dari linguistik, teori sastra dan budaya, filsafat bahasa, sosiologi, dan psikologi. Berdasar studi referensi yang dilakukan, analisis wacana kritis berperan setidaknya dalam tiga bidang pembelajaran, yakni pada peningkatan kemampuan berpikir kritis siswa, kemampuan literasi kritis siswa, serta kesadaran berbahasa kritis pada siswa.

\section{Literasi Kritis}

Definisi literasi kritis terus berubah. Ahli bahasa, ahli pendidikan dan ahli teori sosial berpendapat bahwa literasi bukan lagi didefinisikan sebagai suatu keterampilan nyata; berupa keterampilan membaca dan menulis (Sluys et al, 2006: 199). Lebih dari itu, memiliki kemampuan literasi berarti memiliki kemampuan untuk melakukan berbagai hal yang berkaitan dengan literasi dan menghubungkannya dengan ideologi. Praktek-praktek literasi kritis sering dideskripsikan sebagai pengambilan alternatif pada pembelajaran membaca; termasuk menganalisis bagaimana sebuah teks dapat bekerja secara ideologis. Literasi kritis dalam pembelajaran di sekolah terwujud dalam penggunaan teks-teks pembelajaran sebagai situs penjelajahan kritis, kelaskelas bahasa dan sastra juga memfasilitasi latihan-latihan bagi praktek kebebasan dalam berpendapat. Praktik literasi kritis dapat berkembang menjadi aksi-aksi sosial dalam kelas yang berdampak lebih dari sekadar teks tertulis yang digunakan dalam proses pembelajaran (Sluys et. al, 2006: 199). 
Aktivitas literasi kritis di dalam kelas melibatkan siswa dengan berbagai macam teks, oleh karenanya, pada praktek literasi kritis di dalam kelas perlu adanya pengamatan terhadap wacana yang timbul di dalam kelas. Analisis wacana kritis diperlukan sebagai pemeriksa apakah praktek wacana kelas tersebut dapat dipahami; setiap tuturan, interaksi, gestur, dan keputusan yang terjadi di dalam kelas membentuk apa yang diketahui oleh siswa mengenai kelas dan dunia sosial yang lebih luas. Oleh karena itu, keberadaan analisis wacana kritis sebagai alat pengawasan menjadi penting.

Keberadaan analisis wacana kritis sebagai alat pengawasan diperkuat dengan penelitian Abodeeb-Gentile (2009). Penelitian Abodeeb-Gentile (2009) menunjukkan penggunaan analisis wacana kritis untuk menunjukkan pihak yang dominan (melalui analisis percakapan) berpengaruh terhadap pembentukan identitas literasi kritis siswa. Pada penelitian tersebut, analisis wacana kritis berperan sebagai alat analisis untuk mengetahui tekanan yang terjadi selama pembelajaran literasi kritis di antara siswa yang memiliki kemampuan rendah. Analisis juga dilakukan untuk mengetahui tekanan yang dialami oleh siswa yang dominan.

Dalam praktik literasi kritis di kelas, siswa semestinya diposisikan sebagai agen pembentuk literasi kritis diri sendiri, bukan sebagai subjek pembentukan identitas literasi oleh guru. Perlawanan siswa yang tampak dari analisis wacana kritis yang dilakukan mengacaukan ideologi, khususnya ideologi dalam wacana kelas yang ternyata bertentangan dengan literasi kritis yang dibangun oleh masing-masing siswa.

Analisis wacana kritis yang dilakukan secara cermat dalam upaya peningkatan kemampuan literasi kritis siswa. Analisis wacana kritis diperlukan dalam mendiagnosis hambatan-hambatan yang terjadi selama pembelajaran berkaitan dengan kemampuan literasi kritis yang dimiliki tiap siswa. Diharapkan literasi kritis yang dibangun oleh siswa tidak bertentangan dengan ideologi yang diusung oleh guru dalam pembelajaran literasi kritis tersebut dan sebaliknya. Guru juga dapat mempelajari pola-pola kekuasaan dalam kelas literasi kritis yang mungkin berpengaruh pada kemampuan literasi kritis siswa (terutama siswa dengan kemampuan rendah) dengan melakukan analisis percakapan dan analisis wacana kritis.

\section{Kesadaran Berbahasa Kritis}

Pada bagian sebelumnya, analisis wacana kritis dapat digunakan oleh guru sebagai bagian dari upaya pencarian informasi sekaligus melakukan 
pengawasan terhadap perkembangan siswa dalam literasi kritis. Pada bagian ini, analisis wacana kritis dapat diperkenalkan kepada siswa sebagai salah satu pilihan strategi untuk menunjang kesadaran berbahasa kritis. Kesadaran berbahasa kritis adalah kapasitas mental dan internal yang dibangun secara bertahap oleh pelajar dengan memberikan motivasi dan perhatian secara sadar terhadap sebuah bahasa yang digunakan untuk mencapai pola tertentu (Dar et al, 2010: 459). Kesadaran berbahasa kritis juga merupakan pendekatan pedagodis yang membantu pelajar mengerti cara kerja sebuah bahasa yang berfokus pada hubungan antara bahasa dan konteks sosial. Kesadaran berbahasa kritis ini perlu dimiliki oleh siswa yang melakukan kontak dengan bahasa asing dan budaya asing sehingga mungkin terjadi perpindahan pemikiran dan kepercayaan asing tersebut menggantikan sistem nilai dan kepercayaan yang telah lebih dulu dimiliki oleh siswa.

Gagasan penggunaan analisis wacana kritis untuk meningkatkan kesadaran berbahasa kritis didorong oleh kurangnya kesadaran berbahasa kritis pada siswa merupakan cerminan dari kurangnya kesadaran berbahasa kritis oleh guru (Burns dan Morrel: 8). Kesadaran berbahasa kritis dapat dicapai apabila siswa memiliki kemampuan berpikir kritis dalam bentuk analisis wacana kritis (Dar et al, 2010: 457). Analisis wacana kritis menawarkan perspektif baru dalam penggunaan bahasa yaitu bersifat problematis, merefleksikan sekaligus berdampak pada proses sosial dan ideologi. Berdasar hasil penelitian yang dilakukan Dar et al (2010: 469), analisis wacana kritis terbukti dapat membantu guru dalam mengajarkan kompleksitas bahasa kepada siswa. Tidak hanya itu, siswa juga lebih sadar terhadap fleksibilitas bahasa yang mencakup pikiran, kepercayaan, dan ideologi. Dengan demikian, siswa tidak hanya dapat mengidentifikasi ideologi yang ada dalam sebuah teks dan menyelidiki hal yang salah atau benar, namun juga membuat siswa memiliki kemampuan untuk menyampaikan argumen terkait dengan kepercayaan dan ideologi yang dimiliki oleh siswa.

Berdasar penjelasan di atas, analisis wacana kritis sebagai sebuah alat menawarkan potensi yang mendalam dalam kaitannya dengan pelatihan guruguru, termasuk mengatur jalannya percakapan dan perubahan pembelajaran di dalam kelas yang memungkinkan terciptanya pendayagunaan kelompokkelompok yang masih termarginalkan di dalam kelas. Oleh karenanya, bukan tidak mungkin guru memasukkan teknik analisis wacana kritis dalam kegiatan pembelajaran 
untuk mencapai tujuan pembelajaran tertentu.

\section{Kemampuan Berpikir Kritis Siswa}

Berpikir kritis merupakan seni berpikir, kemampuan untuk menganalisis pikiran dan situasi yang kompleks menggunakan standar obyektivitas dan konsistensi (Paul \& Elder, 2006: xiii, Moore, 2005: 322). Kegiatan berpikir kritis setidaknya melibatkan tiga tingkatan, yakni analisis terhadap pemikiran, evaluasi terhadap pemikiran, serta meningkatkan pemikiran (Paul \& Elder, 2006: xiii). Dengan landasan berpikir kritis yang kini digunakan dalam pembelajaran, siswa diharapkan tidak hanya mempelajari sebuah teks sebagaimana adanya. Siswa diharap menggunakan kemampuan berpikir tingkat tinggi sehingga tidak hanya dapat menyerap pengetahuan yang ada dalam teks, namun juga mengevaluasi teks tersebut.

$$
\text { Berikut adalah beberapa }
$$
keterampilan yang merepresentasikan kemampuan berpikir kritis siswa (Fisher dalam Avendano dan Fonseca, 2009: 39) yaitu , : a) mengenali masalah, b) memperkirakan dampak dari masalah yang ditemukan, c) mengumpulkan informasi yang penting, d) mengenali asumsi dan nilai yang tersirat, e) memahami dan menggunakan bahasa dengan tepat, jelas, dan sesuai konteks, f) menginterpretasi data, g) mengemukakan bukti dan mengevaluasi, h) mengenali keberadaan hubungan logis antar proposisi, i) menarik kesimpulan, j) mengonstruk pola kepercayaan seseorang, k) dan menyampaikan penilaian yang akurat mengenai kualitas suatu benda.

Tuntutan agar siswa memiliki kemampuan berpikir kritis mengharuskan guru dapat menemukan metode, model, sumber, dan strategi yang tepat, salah satunya melalui analisis wacana kritis. Analisis wacana kritis fokus terhadap apa yang dilakukan oleh manusia dengan bahasa dan bagaimana manusia menggunakannya. Pada perspektif pembelajaran bahasa di sekolah, salah wujud dari penggunaan bahasa adalah aktivitas membaca kritis. Penelitian Avendano dan Fonseca (2009: 42) menyingkap piranti analisis wacana kritis yang dapat membantu siswa untuk mengidentifikasi dan menganalisis sebuah teks. Analisis wacana kritis mampu mendeteksi penggunaan kosa kata dan bahasa konotatif dan implisit yang semestinya dikritisi. Penggunaan analisis wacana kritis dalam kegiatan membaca kritis tersebut merupakan salah satu kontribusi analisis wacana kritis dalam upaya peningkatan kemampuan berpikir kritis siswa. Tidak menutup kemungkinan analisis wacana kritis dapat digunakan 
untuk meningkatkan kemampuan berpikir kritis siswa dalam bentuk yang lain.

\section{PENUTUP}

Analisis wacana kritis tidak hanya dapat digunakan untuk menyingkap ideologi yang tersembunyi di balik sebuah wacana. Lebih dari itu, analisis wacana kritis bersifat multidisipliner yang memungkinkan penggunaannya dalam berbagai bidang, salah satunya adalah bidang pembelajaran bahasa. Analisis wacana kritis dapat dijadikan alat untuk membantu siswa maupun guru dalam mencapai tujuan pembelajaran, salah satunya, analisis wacana kritis dapat digunakan sebagai metode untuk meningkatkan kemampuan berpikir kritis, meningkatkan kompetensi literasi kritis, dan kesadaran berbahasa kritis. Analisis wacana kritis memiliki peluang untuk dikolaborasikan dan diterapkan dalam pembelajaran bahasa di sekolah-sekolah. Hal ini tentunya membutuhkan usaha dan kreativitas guru untuk dapat memodifikasi analisis wacana kritis agar dapat dijadikan piranti yang tepat untuk meningkatkan kemampuan siswa.

\section{DAFTAR PUSTAKA}

Abodeeb-Gentile, Theresa L. 2008. A Critical Discourse Analysis of Classroom Literacy Practices in Fourth Grade: The Critical Moments. Disertasi tidak diterbitkan. (Online). (http://scholarworks.umass.edu/diss ertations/AAI3315529/

Avendano, Cesar E.M., dan Maritza H. Fonseca. 2009. Use of Discourse Analysis to Enhance Students Critical Thinking Skills. Zona Proxima 10 Juli 2009.

Burns, Leslie dan Ernest Morrel. Why Critical Discourse Analysis in Literacy Research. Makalah disajikan dalam National Reading Conference Yearbook 54, Michigan State University.

Dar, Zeinab Koupaee et al. 2010. Teaching Reading with a Critical Attitude: Using Critical Discourse Analysis (CDA) tio Raise EFL University Students Critical Language Awareness (CLA). International Journal of Criminology and Sociological Theory, Vol. 3, No. 2, December 2010.

Fairclough, Norman. 2012. The Dialectics of Discourse. (Online), (https://www.sfu.ca/cmns/courses/ 2012/801/1-

Readings/Fairclough\%20Dialectics \%20of\%20Discourse\%20Analysis. pdf), diakses 5 Mei 2015.

Paul, R. and Elder, L. 2006. Foundation For Critical Thinking. London: Routladge and Palmer. Sluys, Katie Van et al. 2006. Researching Critical Literacy: A Critical Study of Analysis of Classroom Discourse. Journal of Literacy Research, 38(2), 197-233

Sheyholislami, Jaffer. 2001. Critical Discourse Analysis. Tesis tidak diterbitkan. Carleton University, Ottawa, Canada. (Online). Diakses 4 Mei 2015.

Weiss, Gilbert dan Ruth Wodak (Eds). 2002. Critical Discourse Analysis: Theory and Interdisciplinarity. New York: Palgrave Macmillan. 